\title{
Displacement and Exile in Evelyn Waugh's Post-War Fiction
}

\begin{abstract}
Evelyn Waugh's later fiction, especially his acclaimed trilogy known as Sword of Honour, is an indispensable source for a first-hand depiction of Britain's involvement in the Second World War. Waugh's millitary service in Croatia from 1944 to 1945 strengthened his concern for the predicament of the displaced persons and exiles he met there. Perhaps the clearest evidence of this new awareness is the privileged space that such characters find in these stories and the degree to which their suffering permeates the narratives they inhabit. My paper discuses Waugh's treatment of displacement and exile in the final stages of the war trilogy and provides a historical background to his presentation of displaced persons, using Papastergiadis's concept of deterritorialization as analytical tool.

Keywords

Evelyn Waugh; Sword of Honour; Scott-King's Modern Europe; displacement; war refugees; World War II in literature
\end{abstract}

For a first-hand depiction of Britain's involvement in the Second World War, Evelyn Waugh's later fiction is an indispensable source, especially his war trilogy known as Sword of Honour, which has received considerable critical acclaim. ${ }^{1}$ Very little, however, has been said about Waugh's treatment of displacement and exile, even though these issues play a vital role in the final stages of the war trilogy. My paper sets out to fill this critical gap by providing a historical background to Waugh's presentation of displaced persons, individuals removed from their native country as refugees or prisoners who have managed to survive the slaughter but at the cost of becoming homeless, dispossessed and materially or spiritually humiliated. 
Even though displacement, migration and exile were not issues entirely absent from Evelyn Waugh's early fiction, at that eminently comic stage they were presented in a farcical context. A good example is Archimadrite Antonios, a war refugee introduced in Put Out More Flags as a fun figure whose major source of comedy derives from his incongruous speech and his overpowering sexual instincts. Indeed, the archimandrite has been expulsed from Sofia "for fornications", though he claims it was for politics too (Waugh 1976: 67). In the chaotic universe of Waugh's early work the displaced person became one more comic element observed with the ironic detachment of the satirist. The Second World War, however, brought about a radical turning point in his awareness of the tragic nature of the world he inhabited and fictionalized. He served in various regiments as an officer and saw battle in the field and behind the lines, but both his own personal burnout and his perception of Britain's role resulted in an "increasing, then permanent despondence" (Patey 1988: 183). He confessed to a friend that life for him had "ceased with the war" (Amory 1982: 432), which implied not only a deep frustration at the fate of Poland, Yugoslavia and other Central and Eastern European nations subjugated under Soviet rule, but also his perception that a new barbarism and materialism had taken over in the civilized West after the war. He was aware that his age had witnessed the biggest massacre in History, with a death toll estimation of around 60 million civilians and soldiers, and that there were millions of other war victims still alive. Waugh's service in Croatia from 1944 to 1945 and his contact with the exiles he met there strengthened his concern for the predicament of the displaced persons (see Gallagher and Villar 2014: 91-130, 253-300). Perhaps the clearest evidence of this new awareness is the privileged space that such characters find in his fiction and the degree to which their suffering permeates the narratives they inhabit. Furthermore, one of them, Mme Kanyi, plays a decisive role in the hero's achievement of his ultimate epiphany.

It is not unusual to relate Waugh's later concern for the displaced persons to a new thematic development, obvious in Helena (1950) and the war trilogy, that seems to spring from this post-war awareness: the human being alone can hardly do anything to change history or alter global structures, but each individual can always do some private acts of service to those around him that will make a difference. Waugh concluded a BBC talk given in 1950 by stating that God "wants a different thing from each of us, laborious or easy, conspicuous or quite private, but something which only we can do and for which we were each created" (Gallagher 1984: 410). Accordingly, his later works can be interpreted in the light of a stronger ethical commitment consistent with a further impregnation of Christian ethos. But there is also a political edge to the depiction of the plight of displaced persons, as their suffering is often presented as a consequence of Britain's policy of support of the Communist regimes that emerged during and after the war. By portraying the predicament of some victims of the Communist "liberation", Waugh returns to one recurrent post-war topic evidencing his frustration with the role that his own country had played in what he saw as "the dismemberment of 
Christendom". Hundreds of thousands of Yugoslav non-Communists, including Mihajlovic's followers -who were forcibly repatriated by the British- ended up in mass graves. Poland had suffered multiple defeats; besides the numerous executions and internments at German and Soviet hands during the war, it had not only lost its territorial integrity but had ended up under the influence of the USSR. Thus, the Preface to the second edition of Waugh's biography of the Jesuit martyr Edmund Campion (1945) mentioned the "news of other saints in the prison camps of Eastern and South-eastern Europe, of cruelty and degradation more savage that anything in Tudor England"; "Tactical Exercise" (1947) portrayed a "clandestine branch of the Foreign Office ... setting up hostile and oppressive governments in Eastern Europe"; Scott-King's Modern Europe (1947) featured the predicament of homeless and nationless Croatian expatriates; and religious and ethnic persecution under the Yugoslav Partisans was a crucial subject-matter in "Compassion" (1948) and later in Unconditional Surrender (1961).

Though Scott-King's Modern Europe (1947), Waugh's first post-war fiction, apparently belongs to the light comedy tradition, its tone gets consistently darker, and so is its depiction of one character emerging as a victim of the new European remapping: Dr Bogdan Antonic. He and his wife are expatriates who have been forced to leave Yugoslavia and take refuge in Neutralia, ${ }^{3}$ though, since they haven't yet obtained naturalization papers, they are willing to move on to the USA, England or wherever they may be accepted. Unlike Archimandrite Antonios, Dr Antonic's characterization does not verge on the absurdly comical; his extreme distress is not so much a caricature as a denunciation of the turbulence in Europe that has forced him (and some millions more) to be permanently on the move. He sums up his plight in one of his earliest speeches:

I am a Croat, born under the Habsburg Empire. That was a true League of Nations. As a young man I studied in Zagreb, Budapest, Prague, Vienna one was free, one moved were one would; one was a citizen of Europe. Then we were liberated and put under the Serbs. Now we are liberated again and put under the Russians. And always more police, more prisons, more hanging. (Waugh 1982: 218)

The fate of Dr. Antonic prefigures Waugh's eventual treatment of the victims of liberation in Unconditional Surrender (1961), a novel whose last section hinges on the troubles of the Kanyis and a group of Jewish refugees held by Tito's partisans in Croatia. Although there is a lapse of fourteen years between the publication of either novel, the Croatian sequence was conceived in 1948 as a short story entitled "Compassion", which Waugh offered to The Month soon after he met its new editor, Fr. Philip Caraman. The fact that Waugh gave "Compassion" for free at a time when he had just told the BBC that they could not afford to commission a story from him (Patey 1998: 288) is a good indicator of his deeply felt need to publicize the persecution of individuals by repressive Communist states at a time when his country's government and public opinion were looking away. 
In "Compassion", finally published in 1949, the role of English benefactor corresponds to an agnostic Major Gordon, and the story's tragic ending is clinched, very much in a manner reminiscent of some Graham Greene novels, ${ }^{4}$ by a final conversation with a chaplain in which the latter offers a sort of consolation on theological-ethical grounds. In turn, Guy's concern with the displaced Jews takes up a long section of Unconditional Surrender, starting in the second chapter of Book III (The Death Wish) and continuing until the end of the novel. In mid-April 1944, while Guy is holding his dreary position as liaison officer in the reduced military mission in Begoy - a fictional projection of Topusko, which was then the Croatian headquarters of the Partisans -, he receives the unusual visit of a crowd of ragged Jews, mostly old, who throng in front of his building demanding to be listened to. They do not look Semitic; most are Slavs who have known better days but are now half-starving in their forced ghetto in Begoy. We learn about the origin of some of them: there is a former grocer from Mostar, a lawyer from Zagreb and a younger woman from Fiume, Mme Kanyi, who will become a relevant character in this final section of the trilogy. Apart from facilitating Guy's ultimate realization that his crusade has been an illusion, she may represent all the victims of the Communist liberation in Eastern and Central Europe after World War II.

The migration analyst Nikos Papastergiadis defines the term deterritorialization as referring to "the way that a national or even a regional culture can no longer be conceived as reflecting a coherent and distinctive identity" (Papastergiadis 2000: 115). The fact that Mme Kanji comes from Fiume (now Rijeka) may be a symptom of deterritorialization. This coastal city was part of the Austro-Hungarian Empire from the early $19^{\text {th }}$ century and was later administered by the Kingdom of Hungary. If Mme Kanyi is presented as "a youngish woman" in 1944, she might have been born before the end of the First World War, so in her rather short life she must have been a subject of different nation-states. With the collapse of the Empire after the Great War Fiume became forcefully contested by Italy and the new state of Yugoslavia. On 12 September 1919 a force of Italian nationalists seized control of the city and established the Italian regency of Carnaro, but two months later the two disputing countries reached an agreement under the treaty of Rapallo, and Fiume became an independent state for a few years. In 1924, however, the Italian fascists in power promoted its annexation to Italy, which lasted for twenty years.

Besides, Fiume itself was a European melting-pot in the late $19^{\text {th }}$ century, since the Kingdom of Hungary had encouraged immigration from all parts of the Empire. According to Taylor (1976: 269), in 1910 (a likely birth year for Mme Kanyi) there were in Fiume 24,000 Italian-speaking, 13,000 Croat-speaking, 6,500 Hungarians (Mme Kanyi herself was married to a Hungarian engineer), and thousands of other nationalities such as Slovenians, Slovaks, Greeks, Germans or Czechs. This variety, plus the political instability of the city in the early $20^{\text {th }}$ century, makes her origin a source of displacement in itself. Moreover, she is Jewish, a fact that, apart from the mythical echoes related to the Wandering Jew (a myth that Waugh revisits in his novel Helena), brings about obvious connotations in the context of the Holocaust. 
Waugh's narrator sums up her predicament since the outbreak of the war when he says that she and her companions were

the survivors of an Italian concentration camp on the island of Rab. Most were Jugo-Slav nationals, but some, like herself, were refugees from Central Europe. She and her husband were on their way to Australia in 1939; their papers were in order; he had a job waiting for him in Brisbane. Then they had been caught by the war.

When the king fled, the Ustachi began massacring Jews. The Italians rounded them up and took them to the Adriatic. When Italy surrendered, the Partisans for a few weeks held the coast. They brought the Jews to the mainland, conscribed all who seemed capable of useful work, and imprisoned the rest ... Then the Germans moved in; the partisans fled, taking the Jews with them. And here they were, a hundred and eight of them, half starving in Begoy. (Waugh 1984: 523)

From his diaries we know that Waugh encountered a similar group of Jewish repatriates while serving in an analogous position in Topusko, which then was the final link in the Allied escape route across the Balkans (Davie 1976: 591). Waugh's first description of the Jews, soon after his arrival in September 1944, is rather detached: "no inhabitants except soldiers and Jews awaiting evacuation who give the Communist salute and write illiterate appeals to Randolph [Churchill, the mission's senior officer]" (Davie 1976: 579). Like the fictional refugees, these had been granted permission by the Allied command at Bari to be evacuated there, but their flight kept on being delayed for months. They were similarly marched towards the airfield only to be marched back to their poor dwellings after hours of inane wait (Davie 1976: 584). On some occasions they called on the British Mission and complained about their neglected priorities and about supplies (1976: 586). The diary references, however, are scattered and rather matterof-fact. Waugh left Topusko in December 1944 and hence we learn no more about the fate of these refugees.

Waugh's fictional treatment of the Yugoslav Jews seems significantly more concerned than the diary notes. As Donat Gallagher points out, Waugh's diaries are not symptomatic of his real worries, they are just "brief jottings about the most interesting events and observations of the day" (Gallagher and Villar Flor 2014: 265) meant for private consumption. Brigadier Fitzroy Maclean confirms that the characters in Unconditional Surrender were based on a similar group, and adds that he himself, as commander of the $37^{\text {th }}$ British Mission to Yugoslavia, did everything he could with Tito "to let them be transshipped" and that Waugh "was very active over this" (Gallagher and Villar Flor 2014: 266). Furthermore, the intensity with which the fate of the Jews is portrayed in fiction is ample proof that Waugh was by no means indifferent to their plight. In fact, their story was the first section ever written of what would later become the war trilogy. 
The Rab Concentration Camp, where the Kanyis and their companions were imprisoned, is well documented. Built near the village of Kampor, it was opened in 1942 for the internment of Slovenian and Croatian prisoners, and was closed in September 1943 after the Italian armistice. Soon afterwards the Germans seized it and some remaining Jewish internees were taken to Auschwitz. The living conditions for the Slovenian and Croatian inmates, about 15,000 at its peak, were appalling; they were left to starve slowly in unhygienic and overcrowded tents. By July 1943, 2,118 Jews are recorded to have been interned by the Italian army, but they were placed in a different section separated from the Croats and Slovenes and they enjoyed better living conditions, were lodged in houses instead of tents, and had proper sanitation and services. According to Jonathan Steinberg, this different treatment arose from the Italian notion that Croats and Slovenes were political enemies, whereas the Jews did not question Italian expansionism and so were seen with less animosity. Furthermore, the Italian officers wanted to distance themselves from the virulent anti-Semitism that characterized their German allies (Steinberg 2002: 34). In fact, on 16 August 1943, shortly before the Italian armistice and consequent closure of the camp, the Italian command issued an order that all the Jews were to be released from the camp unless they wished to stay (Rodogno 2006: 354). Most of the 2,700 Jews held at Rab were evacuated to partisan territory; about 245 joined the ranks of the People's Liberation Army (as Mme Kanyi relates) forming the Rab battalion, but some 200 older or sick inmates were left behind when the Germans took over, and they were eventually sent to Auschwitz for extermination (Zuccotti 1996: 79).

How accurate was Waugh's knowledge of the conditions in Rab camp at the time of writing his fiction? If we analyze Mme Kanyi's testimony above, the detention of the couple may appear slightly mistimed; they were on their way to Australia $^{5}$ in 1939, but got interned after Yugoslavia was invaded by the Axis and the Jews suffered the ensuing repression by the Ustashi government taking over afterwards. ${ }^{6}$ Between the outbreak of the war and Peter II's flight in April 1941 there was an interval of almost one year and a half. And two more years passed between the fall of Yugoslavia and the arrival of the first batch of Jewish prisoners in Rab. But perhaps more significant still is whether Waugh knew of the relatively humane treatment of the Jews in comparison with the other Slovene and Croatian inmates, according to Steinberg. In his first encounter with Mme Kanyi and her companions, Guy regards their predicament with some detachment and does not consider it too overwhelming: "if it was not for the partisans you would now be in the hands of the Nazis" (Waugh 1984: 524), he says to her. But he gradually comes to realize that their confinement in Begoy is hardly better than life at the prison camp. They are crowded together in unhygienic conditions, lacking the essentials - "a needle, a lamp, butter, soap, a pillow" (Waugh 1984: 526) - and live in permanent fear of reprisals if they do something that may upset the partisans, who look upon them with suspicion. Is this an indication that the Jews may have indeed been worse off in Begoy-Topusko than in Rab? 
On the other hand, the fact that the Jews were better treated than the Slovenes and Croats at Rab Camp might explain the strong partisan animosity towards them reflected in Unconditional Surrender. Waugh must have sensed this bitterness during his months at Topusko, but in his fiction, at any rate, he does not grant the partisans this (questionably) extenuating circumstance. Their collective characterization as ruthless, resentful, suspicious, capable of heroism but also of mass-murder if required, makes it easier to make his point about the thwarted liberation brought about by Communist regimes and aided or tolerated by Britain.

One thing that particularly upsets the partisans is the international help given to the Jews, which, they think, would be better employed by their troops. Although the British Mission can do very little for the refugees, luckily there is an organization that provides significant support, UNRRA (United Nations Relief and Rehabilitation Administration), an international relief institution whose main donor was the United States. Founded in Washington in November 1943 with the participation of forty-three governments (Wasserstein 1999: 196), in the time of the story the agency had existed for barely a year - and would not live much longer than 1947. It took over responsibility for refugee relief in Alliedoccupied territories in co-operation with voluntary agencies, distributed goods, food, medicines and tools to nations specially hit by the effects of World War II, and played a major role in helping displaced persons. The chief recipients, according to Hitchcock (2008: 220) were China, Poland, Italy, Yugoslavia (receiving 416 million dollars), Greece, Czechoslovakia, Ukraine and Austria. Although the British government had contributed 80 million pounds to the UNRRA budget in January 1944, the Foreign Office regarded the institution with suspicion and there were numerous complaints about the excessive influence of the American representatives and their strong Zionist sympathies (Wasserstein 1999: 197). In Unconditional Surrender Guy speaks highly of UNRRA to Mme Kanyi, and, although she remains skeptical at first ("What can they do for us?" [Waugh 1984: 527]) the Jews actually receive supplies from the agency, though the partisans retain them for a time.

However, it is not UNRRA that finally provides the long-desired evacuation. In February 1945 Guy learns that the Jews from Begoy have escaped thanks to a "private charitable organization in America", which has transported the exiles through snowy Croatia to Italy in a convoy of new Ford trucks. ${ }^{7}$ For lack of a more detailed reference in the text, we can only conjecture that the most likely organization to have performed that service may be the Jewish Joint Distribution Committee ([J]JDC or simply "the Joint"), a worldwide Jewish relief organization based in New York and operating since 1917. JDC is said to have shipped more than 227 million pounds of food, medicine, clothing, and other supplies to Europe from the US, and Yugoslavia remained a priority (Wasserstein 1996: 207). Its interaction with UNRRA and the occupying forces was a delicate issue: JDC headquarters in New York tried repeatedly to obtain permits from the Allied 
armies to enter their respective zones, but the American and British military leaders rejected any civilian interference in their command areas, a position endorsed by UNRRA in order not to jeopardize relations with the occupation authorities by supporting private welfare organizations (Königseder and Wetzel 2001: 57).

In the account of this exodus, Waugh does not leave out a disquieting element marking the end of the war and the ensuing years: the Displaced Persons Camps, set up by the Allies mostly in Germany, Austria and Italy, to provide shelter for some of the millions who had lost their homes during World War II. They came primarily from Eastern Europe or were former inmates of Nazi Concentration Camps who, for different reasons, could not be repatriated. According to Waxman, nearly 50,000 Jewish survivors ${ }^{8}$ were gathered in such DP camps (Waxman 2006: 92). When Guy visits "his" Jews they are confined "behind barbed wire in a stony valley near Lecce", together with four or five hundred other refugees. Waugh did not go too far from reality in his description of this DP Camp in Lecce. This is probably inspired by "DP number 34", located at Santa Maria al Bagno (formerly Bagni di Santa Maria), borough of Nardo, province of Lecce, which, according to the US Holocaust Memorial Museum report, lodged some 2,300 Jewish refugees from 1944 to 1947.

The Camp Commandant, a British officer that puts Guy "in the picture", believes that these old refugees will remain there till they die (Waugh 1984: 567). Waxman explains how, while around 6 million DPs were successfully repatriated, there were numerous non-repatriable Jewish DPs, most from Eastern Europe, who called themselves, with biblical echoes, she'erit hapletah ('the surviving remnant') and constituted a serious problem for UNRRA and the Allies. The Jewish DPs often complained that they were treated like criminals with curfews and limited rations, and also that they were housed with non-Jewish refugees, some of whom had been collaborators with the Germans (Waxman 2006: 92-93). Waugh's fictional Jews, however, have no hope of being shipped to Palestine, since "the Zionists are only interested in the young" (Waugh 1984: 567). Again large-scale schemes prevail over concern for the individual needs, even among the only institution that seemed to care for the displaced Jews. Indeed, before leaving Bari Guy revisits "the offices where by signal he had begun his work of liberation" (Waugh 1984: 568), arguably those of UNRAA, but this time they are "unsupportive", since their priority is setting up the future State of Israel and won't deal with Jews bound elsewhere. ${ }^{9}$ Although the ultimate responsibility for the management of the camps laid on the Allied armies, through 1945 direct administration was taken over by UNRRA, and JDC was also given more freedom to carry on its relief work in the camps as a consequence of the appointment of Jewish advisers to the US military government (Wasserstein 1996: 16).

The closing chapter of the Croatian section in the trilogy provides a devastating conclusion to Guy's vicissitudes, as he becomes bitterly aware of his thwarted crusade and some important thematic implications are made clear. Guy has already learned the lesson that "quantitative judgments do not apply", ${ }^{10}$ and this final twist of events must be related to an earlier conversation with the pragmatic 
Kerstie Kilbannock before his leaving for Croatia. Regarding Trimmer and Virginia's unwanted child, who Guy was adopting as his own, Kerstie had then said: "Half the population of Europe are homeless -refugees and prisoners. What is one child more or less in all that misery?"; and Guy had replied that he could do nothing about the others, only about this one case (Waugh 1984: 504). Similarly, the camp commandant at Lecce, surprised by Guy's unexpected interest in the Kanyis, asks: "What do two more or less matter?" (Waugh 1984: 567). But at this final stage of the trilogy Guy incarnates his new, humane realization that individual acts of service are still possible amidst the global chaos of wartime; in the face of so much pain and suffering on a worldwide scale, universal lamentations are futile. Once again, short-distance aiming ${ }^{11}$ is the way to avoid total despair and to render a service to someone, even if it is just one person.

But this suggestion -which emerges as one of the major thematic developments in the trilogy- is given a further twist when Guy learns about the tragic fate of the Kanyis, unfairly executed by the partisans. Though neither Guy nor the narrator comments on the execution, this characteristically Wavian economy is hugely eloquent. Guy is aware that the partisans have come to suspect Mme Kanyi because of his dealings with her, purely motivated by his desire to help. At this point in the trilogy's symphonic orchestration a parallelism can be drawn between the unforeseeable consequence of Guy's small services -carrying the lady's loads, or presenting her with chocolate and American magazines- and his early blunder at Apthorpe's deathbed. Indeed, Men at Arms ended with Guy fatally giving his convalescent fellow-Halberdier a bottle of whisky, which eventually speeded up his deterioration and death. So, even if Guy has finally learned the lesson about quantitative judgments, he has not yet fully realized that in this treacherous world even good actions can have fatal outcomes. ${ }^{12}$

The convergence of multiple themes in this short closing chapter illustrates Waugh's sense of narrative architecture. The camp commandant who breaks the news to Guy about the fate of the Jews fulfils another important role. "We're busy at the moment moving people in", he declares. But his self-confident speech is counterpointed by a lapidary narratorial statement: "This man was in fact at that moment busy dispatching royalist officers - though he did not know it - to certain execution" (Waugh 1984: 568). Again the technique works with a succinct text deprived of judgmental interpretation. Waugh's final comment on the fate of displaced people in the war ties in with previous, also succinct interpolations occurring much earlier in the trilogy, when the fate of the Polish prisoners is contrasted with the indolence of the British officers drinking happily at home, far "from those secret forests where the trains were, even then, while the Halberdiers and their guests sat bemused by wine and harmony, rolling east and west with their doomed loads" (Waugh 1984: 60). 


\section{Conclusion}

If biography is allowed to intrude in literary analysis, there seems little doubt that Waugh's military service in Croatia from 1944 to 1945 accentuated his concern for the victims of war. Unlike the absurd émigrés and refugees of his early novels, those inspired by his Yugoslav experience reflect the distress and uprootedness of real sufferers. In SKME, published in 1947, the Croatian Dr Bogdan Antonic has been forced to leave Yugoslavia and cannot return there, lest he be hanged in one of Tito's purges, like the royalist officers dispatched by the British "to certain execution". But Antonic's home is not yet in Neutralia (arguably Spain) since neither he nor his family have obtained naturalization, so they must be ready to pack up and leave if they eventually get expelled. Similarly, the tragicomic ending of the book presents an image of several expatriates of different nationalities using a clandestine network to escape from European authorities: "there were a detachment of Slovene royalists, a few Algerian nationals, the remnants of a Syrian anarchist association, ten patient Turkish prostitutes, four French Pétainist millionaires, a few Bulgarian terrorists, a half-dozen Gestapo men, an Italian air-marshal and his suite, a Hungarian ballet, some Portuguese Trotskyites..." (Waugh 1982: 244). The assorted background of these expatriates - political, religious, terrorist, criminal...- emphasizes the turbulence of European affairs after the war, voicing that if a terrorist must escape from authority to save his life, so must a Sloven royalist for fear he might be repatriated "to certain execution".

One year later, in 1948, Waugh writes a first version of the story of the Jews that will eventually become the final section in Unconditional Surrender. Once again mobility is the stigma of the displaced persons, and the Jewish refugees go through four camps: they are prisoners in Rab, undernourished in the Begoy ghetto, later moved to a drab, formerly Nazi camp held by the Partisans, and finally end up (those lucky enough) in the Allied DP Camp near Lecce, where most of them are expected to meet their death. There seems to be little difference between the living conditions at each of these settings, a fact that stresses the disquieting equality between the warring factions, the conviction that the war had "cast its heroic and chivalrous disguise and became a sweaty tug-of-war between teams of indistinguishable louts" (Waugh 1947: 197). And one of the gravest accusations that can be made to either side is that ideology or expediency have prevailed over the individual. The suffering and death of dozens of millions is taken as collateral damage. If this fatal notion is clearly applicable to Nazism and Stalinism, Waugh's contention is that the rest of the Allies, and Britain in particular, have succumbed to it as well.

One word could be added about the fact that the most pitiful DPs in Waugh's fiction are Jewish. The later developments in the trilogy show a formerly downhearted Guy somehow strengthened in his Christian convictions, as he, who is far from being a Zionist, plunges into the service of people who are not his coreligionists, and from whom he expects to gain nothing. Waugh's technique of verbal economy and foreshadowing - apparently irrelevant incidents or conversations taking on 
an unexpected significance in later segments of the narrative - is here at play. Before the final events in Unconditional Surrender a conversation was recorded between Guy and Frank de Souza, former fellow-probationer, later junior officer, and eventual superior in Begoy. Despite his natural cynicism and skepticism De Souza has become a staunch Communist and is very much involved in the triumph of the Partisan cause in Yugoslavia. He scorns Guy's excessive interest in the Jews, arguing that "the Zionists have their own funds and their own contacts with UNRRA", and insists that there are "more important things to think about than these sectarian troubles" (Waugh 1984: 544-545). In turn, Guy, by committing himself so intensely to the relief of the Jews (later De Souza accuses him of having "an idée fixe" and even of becoming "a psychiatrist's case" [560]) is dissociating himself from whatever partisanship, in the wider sense of the term, he may be tempted to feel. "I can't feel like that about Catholics", he says to De Souza, and this can be interpreted as a refusal to favour a cause, including his own, over individuals. Even UNRRA, which had been supportive so far, refuses to help the group of Jews any longer because most of them are too old to settle in the future state of Israel, which has become their priority. Just as in the first days of the war, when Guy was following up heartbreaking developments such as Russia's invasion of Poland but "found no sympathy among these old soldiers for his own indignation" (Waugh 1984: 21), at the end of the trilogy Guy is still quite alone in his belief that it is individuals that matter. It could be said that Guy also suffers a process of moral deterritorialization (Papastergiadis 2000: 115) in at least two senses; on the one hand, his religion does not become an exclusive space where he enjoys the comforts of identity; and, on the other, he is unable to find a commonly shared and coherent unity of values that might define his own culture against that of the opposing nations in time of warfare. Guy Crouchback becomes a displaced person in his own country. Significantly enough, it is Mme Kanyi, a Jewish refugee, poor, desperate and alarmingly helpless, whom he inadvertently -like the unnamed Commandant at the Lecce camp- has sent to her death, the person who ultimately opens the eyes of an English Catholic officer and aristocrat.

Waugh's thematic implications in the trilogy, and more specifically in its concluding section, have too often been simplified as a political critique of Communism, whose advance during his mature years disturbed him deeply. It is obvious that Sword of Honour has a clearly political edge in its denunciation of World War II politics, but it is not based on a Manichean attribution of virtues and vices. In fact, Guy's early idealism and his neat distinction between civilization and barbarism ("The enemy was plain in view... all disguise cast off") evolves throughout the trilogy as a result of his experience not only with ruthless and biased Partisans or Communist agitators who have infiltrated the British institutions, but also with hard-faced Englishmen who wish to do well out of the war, blind soldiers who do not care about what they are fighting for, aristocrats who become defectors, or conservative politicians who betray the weakest nations in order to save face; and, most alarmingly, with his own realization that he has been one of such men who plunged into war because they could not accept their personal frustrations. ${ }^{14}$ 


\section{Notes}

$1 \quad$ The original trilogy comprises Men at Arms (1952), Officers and Gentlemen (1955) and Unconditional Surrender (1961). Sword of Honour is the title of the revised one-volume version published in 1965, containing some deletions of the original text and a few additions. For the purpose of my analysis I will refer indistinctively to this final version or to each novel of the trilogy.

2 To mention a few appreciative comments, Andrew Rutherford judged the trilogy "probably the greatest work of fiction to emerge from the Second World War" (1978: 113). Cyril Connolly (1952: 337) recognized it as "unquestionably the finest novel to have come out of the war". Holger Klein (1984: 37) agrees that it remains the most substantial exponent of its type so far, and generally among the best books in the field". Regarding its historical value, the military historian Antony Beevor has chosen the trilogy as one of the five best works of fiction about the Second World War; whilst Jeffrey Archer listed it as one of the best romanfleuves in English, adding the familiar remark that it is "probably the best thing in English literature to be inspired by the second world war". For several Waugh scholars Neutralia undoubtedly represents post-war Spain. See, for instance, McDonnell (1988: 128), Wykes (1999: 151-152), or Carpenter (1989: 390-391). A final coda by a priest interpreting the story's climax is a characteristic resource of Greene's so-called "Catholic novels", such as Brighton Rock, The Heart of the Matter, or A Burnt-OutCase.

5 Australia was a common destination for Jewish refugees. According to Michael Cohen, "the Australian Jewish community was transformed in the 1930s and 1940s by the arrival of approximately 8,000 Jewish refugees from Nazi Germany Austria and Czechoslovakia and, slightly later, by approximately 35,000 East European survivors of the Holocaust." After the rapid invasion of Yugoslavia by the Axis in April 1941, the kingdom was dismembered and Germany occupied the north of Slovenia, asserted control over Serbia, and installed a puppet government of Croatia led by the philo-Fascist organization known as Ustasha.

7 In "Compassion", however, it is the British officialdom that provides for the evacuation. As he grew discontented with his own country after the war, Waugh experienced a growing fondness for the USA as "assuming leadership of the "West"” (see Patey 1998: 282). "In the immediate aftermath of the war the term 'survivor' was not yet in common usage, and instead 'Displaced Person' was used” (Waxman 2006: 92).

$9 \quad$ This reply echoes a similar denial noted in Waugh's diaries behind a laconic entry on 25 February 1945: "Saw the Unrra representatives, no good" (Davie 1976: 616). The thematic echo of the term "quantitative judgements" works as a central motif throughout Unconditional Surrender. It is first used by Guy's father - a figure who embodies moral authority throughout the trilogy - censuring his son for applying too worldly judgments on important issues of life, especially in matters of faith. After the death of Mr Crouchback, his last advice held a special sonority in Guy's conscience, and helped him tackle the final stage of the war with a new mind.

11 Waugh may be using the recurrent echoes of a lesson on distance-aiming throughout the trilogy to symbolically convey that Guy must learn not to waste emotional ammunition in attempting to change the world and should rather aim at shorter-distance targets. For a discussion of this symbolic implication, see Villar Flor (2015).

12 One of Waugh's earlier illustrations of the tragic consequences of imprudent good-will is his masterful short story "Mister Loveday's Little Outing" (1936), in which an idle upperclass girl is convinced that a psychopathic murderer confined in a mental asylum is already rehabilitated, so she strives to release him.

13 I wish to thank Professor Patrick Query for reading this manuscript and for his insightful comments and suggestions. 


\section{References}

Amory, Mark (ed.) (1982) The Letters of Evelyn Waugh. Harmondsworth: Penguin.

Archer, Jeffrey (2012) "Jeffrey Archer's Top 10 Romans-fleuves". The Guardian, 14 March 2012: http://www.guardian.co.uk/books/2012/mar/14/Jeffrey-archer-top-10-romans-fleuves (accessed 12 Jan 2016).

Beevor, Antony (2009) "Five Best: World War II Fiction". Wall Street Journal, 21 November: http://online.wsj.com/article/SB1000142405274870443180457454 0113805301456.html (accessed 12 Jan 2016).

Carpenter, Humphrey (1989) The Brideshead Generation: Evelyn Waugh and his Friends. London: Faber and Faber.

Cocoli, Isabela (2015) "EU: Migrant Crisis Worst since World War II" http://www.voanews.com/ content/eu-migrant-crisis-worst-since-world-war-ii/2918256.html (accessed 4 Sept 2015).

Cohen, Michael (1988) Asia-Pacific Survival Guide for the Jewish Traveller. Melbourne: AsiaPacific Jewish Association, adapted at www.jewishaustralia.com/?Page $=$ communityhistory (accessed 3 September 2015).

Connolly, Cyril (1952) "Men at Arms" in Sunday Times, 7 September 1952, 5, in Stannard, 337.

Davie, Michael (ed.) (1976) The Diaries of Evelyn Waugh. London: Weidenfeld and Nicolson.

Gallager, Donat and Carlos Villar Flor (2014) In the Picture: The Facts and Myths behind Evelyn Waugh's Sword of Honour. Amsterdam and New York: Rodopi.

Gallagher, Donat (ed.) (1984) The Essays, Articles and Reviews of Evelyn Waugh. London: Methuen.

Hitchcock, William I. (2008) A Bitter Road to Freedom: A New History of the Liberation of Europe. New York: Simon and Schuster.

Kaczmar, Olga (2015) "Santa Maria al Bagno", http://www.dpcamps.org/santamariabagno.html (accessed 30 August 2015).

Klein, Holger (ed.) (1984) The Second World War in Fiction. London: Macmillan.

Königseder, Angelika and Juliane Wetzel (2001) Waiting for Hope: Jewish Displaced Persons in Post-World War II Germany. Evanston, IL: Northwestern University Press.

McDonnell, Jacqueline (1988) Evelyn Waugh. Houndmills: Macmillan.

Papastergiadis, Nikos (2000) The Turbulence of Migration. Cambridge: Polity Press.

Patey, Douglas Lane (1998) The Life of Evelyn Waugh: A Critical Biography. Oxford: Blackwell.

Rodogno, Davide (2006) Fascism's European Empire: Italian Occupation During the Second World War. Cambridge: Cambridge University Press.

Rutherford, Andrew (1978) The Literature of War: Five Studies in Heroic Virtue. New York: Harper.

Stannard, Martin (ed.) (1984) Evelyn Waugh: The Critical Heritage. London: Routledge and Kegan Paul.

Steinberg, Jonathan (2002) All Or Nothing: The Axis and the Holocaust, 1941-1943. London: Routledge.

Taylor, A. J. P. (1976) The Habsburg Monarchy, 1809-1918. Chicago: University of Chicago Press.

United States Holocaust Memorial Museum (2015) "Santa Maria di Bagni”, http://www.ushmm. org/exhibition/displaced-persons/camp7b.htm (accessed 30 August 2015).

Villar Flor, Carlos and Robert Murray Davis (eds.) (2005) Waugh Without End: New Trends in Evelyn Waugh Studies. Bern: Peter Lang.

Villar Flor, Carlos (2015) "Happy Warriors in Arms: Aspects of military Life in Evelyn Waugh's Put Out More Flags and Sword of Honour". War, Literature and the Arts 27: 1-24. http://wlajournal.com/wlaarchive/27/Flor.pdf (accessed 4 February 2016).

Wasserstein, Bernard (1996) Vanishing Diaspora: The Jews in Europe since 1945. London: Hamish Hamilton.

Wasserstein, Bernard (1999) Britain and the Jews of Europe 1939-1945. London and New York: Leicester University Press.

Waugh, Evelyn (1937) Decline and Fall (1928). Harmondsworth: Penguin. 
Waugh, Evelyn (1976) Put Out More Flags (1942). Harmondsworth: Penguin.

Waugh, Evelyn (1982) Scott-King's Modern Europe (1947). In: Work Suspended and Other Stories, Harmondsworth: Penguin.

Waugh, Evelyn (1984). The Sword of Honour Trilogy: Men at Arms (1952), Officers and Gentlemen (1955), Unconditional Surrender (1961). Harmondsworth: Penguin.

Waugh, Evelyn (1987) Edmund Campion (1935). London: Cassell.

Waxman, Zoë Vania (2006) Writing the Holocaust: Identity, Testimony, Representation. Oxford:

Oxford University Press.

Wykes, David (1999) Evelyn Waugh: A Literary Life. London: Palgrave Macmillan.

Zuccotti, Susan (1996) The Italians and the Holocaust: Persecution, Rescue, and Survival. Lincoln

NE: University of Nebraska Press.

CARLos Villar Flor teaches literature at the University of La Rioja (Spain). He has recently co-authored In the Picture: The Facts behind the Fiction in Evelyn Waugh's Sword of Honour (Rodopi, 2014, with Donat Gallagher) and is the author of critical editions and Spanish translations of Waugh's Men at Arms, Officers and Gentlemen, Unconditional Surrender, Put Out More Flags and Scott-King's Modern Europe, and of George Orwell's Down and Out in Paris and London. He is co-editor of Waugh Without End: New Trends in Evelyn Waugh Studies (Peter Lang, 2005, with Robert Murray Davis), and is currently researching on Graham Greene's travels around the Iberian Peninsula. He has published three novels in Spanish, two short story books and some poetry.

Address: Carlos Villar Flor, Edificio de Filología Universidad de La Rioja, c/ San José de Calasanz, 33, 26006 Logroño, Spain. [email: carlos.villar@unirioja.es] 